\title{
A Comparative Study between TPS and LRD Strategy to Enhance Students' Reading Comprehension
}

\author{
Apricia Tampubolon ${ }^{1}$, Nelson Balisar Panjaitan ${ }^{2}$ \\ Perguruan Advent Pasir Putih ${ }^{1}$, Pekan Baru, Univ. Advent Indonesia ${ }^{2}$ \\ Corresponding Author, Nelson² (sonnelunai@yahoo.co.id)
}

\begin{abstract}
The purpose of this study is to find out if there is any significant difference in students' reading comprehension enhancement between those who were taught using Listen-Read-Discuss strategy and those who were taught using Think-Pair-Share strategy. This study is a quantitative research method using comparative design by using pre-test and post-test. This study was designed to find out the answer of the following question: Is there any significant difference on students' reading comprehension enhancement between those who were taught by Think-Pair-Share strategy and those who were taught by Listen-Read-Discuss strategy. The sample of this study were two classes of grade VIII SMPN 10 Cimahi, Bandung. Grade VIII F were taught using Think-Pair-Share and grade VIII were taught using Listen-ReadDiscuss. The instrument used for this study was a reading comprehension test, which contained of 39 multiple-choice questions. The result of this study showed from the mean score that both classes had an enhancement in their reading comprehension. In addition, there was no significant difference between those who were taught using TPS and those who were taught using LRD strategy. However, it meant that both strategies were efficient in enhancing students' reading comprehension.
\end{abstract}

Keywords: Think-Pair-Share, Listen-Read-Discuss, Reading Comprehension

\section{Introduction}

English is an international language in the world, so learning English is very important in oral and written communication. Indonesian students often experience problems when learning English (Katemba, 2019). In Indonesia English is not their first language that is why reading English text is not easy because English is a foreign language for them. According to Morrisson (2014), English is a difficult subject because it is not the first or second language for them. "Usually students face many problems in reading text. For example: difficult words, comprehension of sentences, how to read the word or sentence correctly and etc." (Katemba, C., Samuel. 2017). So, English is a tense lesson for them.

To improve learning English as a foreign language (EFL) in developing countries like Indonesia, one must start from an early age (Marlina, 2012). Meanwhile (Karimi \& Veisi, 2016) argued that reading resilience can overcome serious problems of students (EFL) in reading, understanding, and translating texts. In dealing with today's modern era, students are required to read a lot and be able to understand English texts so that they are not left behind in the development of science and in addition they are required to achieve academic success and social 
success (Lacina, Bauml, \& Taylor, 2016).

In learning languages there are four skills, namely reading, writing, speaking and listening. Among the four skills, reading skill is something that is equally important to learn because by reading students will gain knowledge. There is a quote stating that reading is a window to the world. It means that through reading students can get in-depth knowledge and other information they need.

In Indonesia reading is a problem. People in Indonesia are less interested in reading not only less interested in reading English books but also in reading Indonesian books. It is showed by "Most Littered Nation in the World" study held by Central Connecticut State University in March 2016. Indonesia ranked 60th out of 61 countries about reading interest that is why the condition of Indonesian people in reading is quite alarming (Gewati, August 2016). Meanwhile, Has, et al., (2016) stated the observation result when conducted teaching practice in class IX of MTS Muhammadiyah 1 Pekanbaru, the students' reading ability is still poor. Students cannot understand the main idea and get the content of the text. In fact, according to the experience of the researcher in learning English, the different background of the students affects the ability of the students in comprehending English text.

According to Hasanah (2016), there are several reasons why students were weak on reading. Firstly, students are less efficient in reading because they lack reading books. In other words, if the students read rarely, they might have problem in acquiring vocabulary. Secondly, students are unable to use context clues to guess the word meaning. If the students come across difficult words, they tend to ignore them, and this discourage and stop them from reading.

The factor that creates the above problem is because students do not converse in English outside the classroom, as a result they do not have the ability to express their idea in English. The other factor that influence students' reading skill is the teaching learning process. Some teachers who teach reading still use the old method and strategy. Their teaching style is teacher-centered, so the students do not have any chance to share their idea to their friends. Their classroom environment is uninteresting because there is no discussion during the teaching and learning process (Hasanah, 2016).

In teaching and learning teachers rarely use cooperative learning model. The teacher just asks the students to listen to the explanation of the teacher and after that let the students do the tasks. They do not have any opportunity to discuss with their friends the subject matter, that is why students with low ability tend to ignore the lesson because they do not understand and when they ask the teacher, they feel ashamed to their friends. However, when the teacher forms the class as a pair or a group, the students will feel more ease to ask their friends in groups without feeling ashamed anymore.

Concerned with this matter, to improve the reading comprehension of eighth grade students of Junior High School in SMPN 10 Cimahi, the researcher proposed the cooperative learning strategy to enhance students' reading comprehension. Cooperative learning gets more students' participation. Students work in pairs or in small groups. This strategy leads students to feel more positive about themselves, and about each other, and the subject they are studying. Students can share with their friends what they think about the subject. This way is more effective and becomes essential for the students' skills than when they learn apart from each other (Has, et al., 2016).

There are many models in cooperative learning that may be used for teaching reading, such as Listen-Read-Discuss, CIRC, Think-Pair-Share, Snowball Throwing, 
Jigsaw, etc. From all the models in cooperative learning the researcher decided to choose Think-Pair-Share and Listen-Read-Discuss to help students overcome their problem in reading because both strategies are expected to be able to enhance students 'reading comprehension. Many researchers have used this strategy to enhance students' reading comprehension and most of them have succeeded in enhancing students 'reading comprehension. Therefore, the researcher decided to choose both strategies to enhance students' reading comprehension.

Think-Pair-share is a strategy that encourages the students to think personally and give the students time to discuss in pairs so that they have a chance to help each other during the discussion then share their ideas in class as a whole so that all students can listen to their friends and get new knowledge. As Ridwan (2016) said that Think-Pair-Share strategy can be used to enhance reading comprehension because it requires students to think about what they will share, then ask them to have a discussion. The teacher gives students time to think, discuss with their partners, and ask them to share their ideas to create more important information. This strategy provides an opportunity for all students to share and express their ideas with other students. This increases their sense of involvement in learning activities in a more challenging class.

Another strategy is Listen-Read-Discuss that give the students time to listen to the teachers' explanation after that, the teacher ask the students to read and while reading, they mark the fluster sentences or words that they find in reading then they discuss it groups that consist of 4-5 students. As Retmawasari (2013) said that the LRD strategy also can be used to improve students' reading skill. The Listen Read Discuss (LRD) strategy has three important elements related to capabilities, namely Listen, Read, and Discuss. LRD is a strategy designed for learning reading comprehension. Students get supplies from Listen step before reading, so when reading students find it easier to get the right ideas and facts about a reading. Students are also invited to compare their findings with other students in group discussion.

Concerned with the explanation above, in order not to make problems happen continuously, the researcher is interested in using TPS and LRD strategies to improve students' reading comprehension, therefore the researcher decided to make a research entitled "A Comparative Study between Think-Pair-Share and ListenRead-Discuss strategy to Enhance Students' Reading Comprehension.”

\section{Statement of the Problem}

Based on the background above, this research focused on finding answer to this question, 'Is there a significant difference in students' reading comprehension enhancement between those who were taught using Think-Pair-Share (TPS) and those who were taught using Listen-Read-Discuss (LRD) strategy?'

\section{Hypothesis}

The hypotheses in this study are:

Null Hypothesis (H0): There is no difference in students' reading comprehension enhancement between those who are taught using Think-Pair-Share and those who are taught using Listen-Read-Discuss strategy.

Alternative Hypothesis (Ha): There is a difference in students' reading comprehension enhancement between those who are taught using Think-PairShare and those who are taught using Listen-Read-Discuss strategy. 


\section{Related Literature \& Studies}

Reading is one of four skills in language. Through reading, students can increase their knowledge and enrich their words. As students, they need to read because in understanding the lessons students must read material. As Ergul (2012) stated that reading difficulty was the main reason for failing in class. According to Supriyani, et al., (2017) "Reading is one of the language skills and it is very important. The purpose of reading is to get information, especially knowledge about something they did not know before, to know." This means reading is needed by students.

Leipzig (2001) stated that reading requires words of recognition, understanding, and fluency.

According to Pang, et al., (2009) and Richards and Schmidts (2002), Reading is to understand written text. This is a complex activity involving understanding ideas. Reading consists of two related processes: word recognition and ability.Word recognition refers to the process of understanding the writing symbols. Readers usually use background knowledge, vocabulary, grammatical knowledge, experience with text and other strategies to help them understand the text.

Thus, for the explanation above the researcher make an inference that reading is very important because through reading readers can get knowledge and information, and while reading readers need to comprehend the reading so that readers can get the knowledge from the text that they have read.

\section{Reading Comprehension}

Reading comprehension is very important because reading without understanding is useless. When students have good reading habits, they will have a lot of knowledge. Some EFL students find it difficult to understand what they are reading. Based on Sapsuha and Bugis (2013) who stated that reading comprehension is useful to obtain information from texts and a skill to be able to evaluate students' vocabulary and also to analyze their meaning. Reading comprehension is also explained as the process of regulating the meaning of the text, which uses one type of reading that is to get specific information. This is active learning that lead the readers to interpret specific ideas of text and information, whether it is about how to express details or inset details and textual references.

Reading is different from reading comprehension. Most people can read but that does not mean that they can understand what they are reading. Reading comprehension is not the ability to read, but the ability to understand text and interpret text based on the features of the text and their own knowledge (Leon, et al., 2012). Reading comprehension is considered as the real core for reading process (Hasanah, 2016). According to Gibson (2009), reading is thinking. Think to understand written text while understanding is known as a skill that focuses on understanding. There are several factors that make reading comprehension a problem. They are environmental, emotional and physical (Jennings, et.al. 2010). In English curriculum for Junior High School, the basic competence of reading is students are able to respond to meaning and rhetorical steps in short simple essay accurately, fluently and acceptable in descriptive and recount text (Purwanti, 2017). 


\section{Challenges in Reading Comprehension}

Reading and Comprehension are two different things. If the readers read the book without comprehending, it said that the readers are only reading. But if the readers read a book with knowing what they have read, it said that they comprehend the reading text. Reading with comprehension is not easy. Some readers get challenges while reading. According to Nation (2016) cited from Dwiono (2017) in teaching and learning reading comprehension there are some problems that will be faced by the students in reading comprehension, they are as follows:

\section{Decoding}

Students who have problems in reading have difficulty decoding words and sentences. Students see words and read them without strive, even if they do not know the meaning of every word. (Nation, 2016). Inference making Numerous studies have demonstrated that in comprehending they have difficulty drawing inferences when reading. (Nation, 2016) Working memory Verbal working memory weakness may be a consequence of poor

Knowledge language comprehension. (Nation, 2016)

Without an appreciation of the meanings of words, there can be no comprehension. (Nation, 2016)

Prior knowledge

Prior knowledge about a text predicts comprehension of it and it is plain that complete lack of knowledge will result in a complete lack of comprehension. (Nation, 2016).

\section{Cooperative Learning}

Human beings are social beings by nature. Therefore, people need to be complicated in social communication with others in various aspects of everyday affairs. One way to achieve such needs is socialization. It is the formation of groups that work for educational purposes. Most likely no person has not experienced involvement in group work during his education (Gurk, 2016).

Hasanah (2016) stated that students at the eighth grade of SMP Nurul Islam Semarang have a problem in reading comprehension. Almost all of the students have difficult to understand the reading text and it affects the student achievement in teaching and learning process. Pertiwi (2015) said that cooperative learning can be very good to enhance students' reading comprehension, because students can work together and help each other to overcome the task at hand. There are many strategies in cooperative learning. Among all strategies in cooperative learning, the researcher is interested in Think-Pair-Share and Listen- Read-Discuss strategies.

\section{Think-Pair-Share Strategy}

Think-Pair-Share is a technique of Cooperative Learning that was developed by Frank Lyman from the University of Maryland in 1978 (Slavin 2005, cited from Fitrahady study, 2015). This is a cooperative learning strategy that includes three components; Think, Pair and Share. Think, Pair and Share is one of the kinds of Cooperative Learning. Cooperative learning is group learning activity organized so that learning is dependent on the socially structured exchange of information between 
learners in groups and in which each learner is held accountable for his/ her own leaning and is motivated to increase the learning of others (Rohman, 2017).

TPS is a collaborative learning strategy that make students work together to solve a problem or answer a question from the text. This technique expects students to think individually about a topic or answer to a question and share ideas in front of class (Afrilianti, 2014). TPS as one of the cooperative learning strategy which consists of three parts, such as thinking, pairing, and sharing. Teachers are not the only the source of knowledge anymore (teacher oriented) but students are included to find and understand new concepts (Suryanita \& Suditha, 2013). Gusdin (2014) said that ThinkPair-Share is a cooperative teaching strategy that includes three components; time to think, time to share with partner and time for each pair to share again with a larger group.

The use of Think-Pair-Share brings together cognitive and social aspects of learning, promotes the development of thought and knowledge. This strategy is suitable to be applied in improving students' reading comprehension, where the focus is a meaningful discussion to exchange ideas and be able to understand skills and strategies to foster understanding (Carss, 2007).

TPS strategy is a good way to improve students' reading comprehension because through this strategy students have the opportunity to work in pairs and share their ideas so that learning cannot be passive.

\section{The Listen-Read-Discuss Strategy (LRD)}

Besides TPS strategy the researcher was also interested to use Listen-ReadDiscuss (LRD) strategy in order to enhance students' reading comprehension. According to Elfa (2017), LRD is a simple strategy, to help students comprehend the reading a text in a small group that consist of 4-6 students. Moreover Putri (2013) said that Listen-Read-Discuss strategy is relatively easy to create because they can enhance student's understanding of many lessons.

The LRD is the strategy that builds students' background knowledge in comprehending the text. It might be active teaching and learning process for the students and the teacher in teaching reading comprehension (Hutomo, 2017). According to Pariska (2016), Listen - Read - Discuss strategy is a strategy which help students understand text. The teacher gives a short lecture to the students. Then the students read the text that the teacher spoke about. After reading, the students discuss the information they have read and the lesson which the teacher gave. This strategy also helps the students use their prior knowledge.

LRD strategy is a strategy help students in understanding the material because they listen to the teacher's explanation and also read the text and discuss the material in group discussion and also discuss in class as whole.

\section{Research Methodology}

This research is quantitative method and it is a comparative study, where the researcher would test the comprehension of the students by giving the pre-test before and post-test after the treatment. The purpose is to find out if there is any significant difference of students' reading comprehension enhancement between those who were taught using TPS and those who were taught using LRD strategy. The research design is described in the following table: 
Table 1. Research Design

\begin{tabular}{|l|l|l|l|}
\hline Group & Pre-test & Treatment & Post-test \\
\hline 1 & $\mathrm{O}$ & $\mathrm{X} 1$ & $\mathrm{O}$ \\
\hline 2 & $\mathrm{O}$ & $\mathrm{X} 2$ & $\mathrm{O}$ \\
\hline
\end{tabular}

\section{Explanation:}

O: Reading Comprehension Test

X1: Treatment of using Think-Pair-Share

X2: Treatment of using Listen-Read-Discuss

\section{Population and Sample}

In this research, the population are students of SMPN 10 Cimahi, Bandung.

The sample was taken from two classes of eighth grade students in SMPN 10, Cimahi. Further, this research was experimental and the strategies that were used in this research were Think-Pair-Share and Listen-Read-Discuss.

\section{Research Instrument}

The instrument of this research was reading comprehension test for pre-test and posttest. The pre-test was designed to measure the ability of the students in enhancing reading comprehension before applying the TPS and LRD strategy while, the post-test was designed to see the result of the study after applying each of the strategy. The reading comprehension test is multiple-choice questions. Hence, the teaching materials that is used in this study is the compilation of descriptive and recount text focused for grade VIII that was made by researcher.

\section{Data Gathering}

\section{Preparation Stage}

In this research, the preparations that were done by researcher were preparing the lesson plan for 8 meetings and preparing the research instrument. Besides, the researcher asked the permission letter from dean of the faculty to conduct the research.

\section{Data Collection}

In gathering the data, the researcher did the following steps:

\section{a. Pilot Test}

b.

The pilot test was being conducted to know the validity and reliability of the test. The test was adopted from previous questions of National Examination (UN) which focused on Descriptive and Recount text of Junior High School level regarding the reading section. The Pilot test consisted of 50 multiple-choice questions. And the test was given to third grade of SMPN 10 Cimahi. The students circled the correct answers on the options given, 2 points for the correct answers and zero (0) points for the wrong answers or no answers. 


\section{c. Pre-Test}

The pre-test was used in order to know the students' reading comprehension level before the treatment was given. The test was given to the respondents of this study, which was the 2nd grade of SMPN 10, Cimahi. And the pre-test was the result of the pilot test that had been conducted to find out the reliability and validity. Further, the test consisted of 39 questions. The students circled the correct answers on the options given, 2 points for the correct answers and zero (0) points for the wrong answers or no answers.

\section{d. Treatment}

After administering the pre-test, the treatment was conducted to the students. The treatment was conducted using two strategies, where one class was taught using ThinkPair-Share and while the other class was taught using Listen-Read-Discuss strategy.

There were several steps in exploiting the Think-Pair-Share and Listen-Read-Discuss strategy. The Think-Pair-Share strategy was adopted from Lyman (1981). The ListenRead-Discuss was adopted from Manzo, A.V., \& Casale, U.P. (1985). The several steps can be seen in the following table.

\section{Several Step of Both Strageies Think-Pair-Share and Listen-Read-Discuss}

\section{Think: Each member individually} and silently thinks about a question posed by the teacher.

2. Pair: Two members are paired to exchange and discuss their responses.

3. Share: Each member may share his response, his partner's response, in a whole class by read it or say it directly. (The researcher formed groups of pairs which are heterogeneous based on the result of the last test given by the room teacher.)

\section{Listen-Read-Discuss}

1. Listen: The researcher presents information to students about the text they will be reading. This can be in the form of a short lecture on a topic, using a graphic organizer to guide the lecture.

2. Read: Ask students to read a text selection. The content should be similar with the material presented during the "listen" portion of the lesson.

3. Discuss: Lead a classroom discussion of the material. Encourage students to reflect on any differences between their reading of the content and teacher's presentation. (The researcher divides students into heterogeneous group based on the previous test Score of the students given by the room teacher).

\section{Post-test}

The post-test was given after giving the treatment to the students to see their enhancement in reading comprehension. The Post-test was used to examine the effectiveness of the strategy. The Post test is the same as the Pre-test which is adopted 
from previous National Examinations (UN) which focused on Descriptive and Recount text of Junior High School level regarding the reading section. It consisted of 39 multiple choice questions.

\section{Statistic Procedure}

The researcher used the statistical program in analyzing the data such as SPSS, Anates, and Microsoft Excel.

Data Analysis on Pilot Test

Before doing the research, the pilot test was administered in SMPN 10 Cimahi that consisted of 50 multiple-choice questions to measure the validity and reliability of the instrument.

\section{Validity Test}

Validity refers to the degree in which test or other measuring device is truly measuring what researcher intended it to measure. Analysis of the validity of the items is done to determine the validity of an instrument.

The following formula was used to test the validity of the instrument.

$$
r_{x y}=\frac{n \sum_{i=1}^{n} X_{i} Y_{i}-\sum_{i=1}^{n} X_{i} \sum_{i=1}^{n} Y_{i}}{\sqrt{\left\{n \sum_{i=1}^{n} X_{i}^{2}-\left(\sum_{i=1}^{n} X_{i}\right)^{2}\right\}-\left\{n \sum_{i=1}^{n} Y_{i}^{2}-\left(\sum_{i=1}^{n} Y_{i}\right)^{2}\right\}}}
$$

(Arikunto, 2012)r $r_{x y}=\frac{n \sum X Y-\left(\sum X\right)\left(\sum Y\right)}{\sqrt{\left[n \sum X^{2}-\left(\sum X\right)^{2}\right]\left[n \sum Y^{2}-\left(\sum Y\right)^{2}\right]}}$ (Arikunto 2009)

Where;

$\mathrm{r}_{\mathrm{xy}}=$ product correlation coefficient

$\mathrm{X}=$ Score item

$\mathrm{Y}=$ Total Score

$\mathrm{N}=$ Number of participants

The criteria of validity test are shown in the following table 3.2 (Arikunto, 2012):

Table 2. Validity Criteria

\begin{tabular}{|c|c|}
\hline $\mathbf{r}_{\mathrm{xy}}$ & Interpretation \\
\hline $0.80 \leq \mathrm{r}_{\mathrm{xy}} \leq 1.00$ & Very high \\
\hline $0.60 \leq \mathrm{r}_{\mathrm{xy}} \leq 0.79$ & High \\
\hline $0.40 \leq \mathrm{r}_{\mathrm{xy}} \leq 0.59$ & Moderate \\
\hline $0.20 \leq \mathrm{r}_{\mathrm{xy}} \leq 0.39$ & Low \\
\hline $0.00 \leq \mathrm{r}_{\mathrm{xy}} \leq 0.19$ & Very low \\
\hline
\end{tabular}

The result as follows: 
Table 3. Validity Question

\begin{tabular}{|c|c|c|}
\hline Number of Questions & $r_{x y}$ & $\begin{array}{l}\text { Interpretati } \\
\text { on }\end{array}$ \\
\hline- & $0.80 \leq \mathrm{r}_{\mathrm{xy}} \leq 1.00$ & Very high \\
\hline $2,19,32,50$ & $0.606 \leq \mathrm{r}_{\mathrm{xy}} \leq 0.654$ & High \\
\hline $\begin{array}{c}3,14,17,18,20,22,27,28,31,33,34,35,36 \\
39,40,41,48,49\end{array}$ & $0.408 \leq \mathrm{r}_{\mathrm{xy}} \leq 0.586$ & Moderate \\
\hline $12,16,21,30,37,44,45,46$ & $0.215 \leq \mathrm{r}_{\mathrm{xy}} \leq 0.342$ & Low \\
\hline $4,6,10,15,23,24,26,42,43$ & $0.031 \leq \mathrm{r}_{\mathrm{xy}} \leq 0.161$ & Very low \\
\hline $1,5,7,8,9,11,13,25,29,38,47$ & $\begin{array}{c}-0.044 \leq \mathrm{r}_{\mathrm{xy}} \leq- \\
0.447\end{array}$ & Not valid \\
\hline
\end{tabular}

Based on the result above, the questions that were valid if the score was larger than 0.00 . From the table above, there were 39 items that were valid. There were 4 items that were high, 18 items were moderate, 8 items were low, 9 items were very low, and 11 items that are not valid.

Reliability

Reliability analysis is done to find out if the instrument of the question has given consistent results. The reliability of an instrument can be seen from the instrument itself. The formula that was used to find the reliability of the instrument is alpha's formula:

$$
\begin{gathered}
r_{11}=\left(\frac{n}{(n-1)}\right)\left(1-\frac{\sum \sigma_{i}^{2}}{\sigma_{t}^{2}}\right) \\
\text { (Arikunto, 2012) } r_{11}=\left(\frac{n}{n-1}\right)\left(\frac{s^{2}-\sum p q}{s^{2}}\right) \cdots \cdots \cdots \cdots \text { (Arikunto, 2012) }
\end{gathered}
$$

Where;

$r_{11}$ : Reliability all test

$n$ : Total number of questions

$\sum \sigma_{i}^{2}$ : Total score of each question variance

$\sigma_{t}^{2}:$ Variance

Here are the criteria of reliability level according to Arikunto (2012):

Table 4. Classification of Reliability

\begin{tabular}{|l|l|}
\hline \multicolumn{1}{|c|}{ Coefficient reliability } & \multicolumn{1}{c|}{ Interpretation } \\
\hline $0,00 \leq r_{11} \leq 0,20$ & Very low \\
\hline
\end{tabular}




\begin{tabular}{|l|l|}
\hline $0,21 \leq r_{11}<0,40$ & Low \\
\hline $0,41 \leq r_{11}<0,60$ & Moderate \\
\hline $0,61 \leq r_{11} \leq 0,80$ & High \\
\hline $0,90 \leq r_{11} \leq 1,00$ & Very high \\
\hline
\end{tabular}

Here are the criteria of reliability level according to Arikunto (2012):

Table 5. Classification of Reliability

\begin{tabular}{|l|l|}
\hline \multicolumn{1}{|c|}{ Coefficient reliability } & \multicolumn{1}{c|}{ Interpretation } \\
\hline $0,00 \leq r_{11} \leq 0,20$ & Very low \\
\hline $0,21 \leq r_{11}<0,40$ & Low \\
\hline $0,41 \leq r_{11}<0,60$ & Moderate \\
\hline $0,61 \leq r_{11} \leq 0,80$ & High \\
\hline $0,90 \leq r_{11} \leq 1,00$ & Very high \\
\hline
\end{tabular}

The reliability level of the pilot test is 0.66 , which means it has a high level.

Discrimination Index

The discrimination index of item is the ability to discriminate between good students (high ability) and the students who were less in intelligent (low ability).

The following formula was used to calculate the item:

$$
D=\frac{B_{A}}{J_{A}}-\frac{B_{B}}{J_{B}}=P_{A}-P_{B}
$$

(Arikunto, 2012)

Explanation:

$\mathrm{D}$ : Discriminate index

$\mathrm{J}:$ Number of the test participants

$\mathrm{J}_{\mathrm{A}}$ : Number of upper group participant

$\mathrm{J}_{\mathrm{B}}$ : Number of lower group participant

$B_{A}$ : Number of upper group participants who answered the question correctly

$B_{B}$ : Nımher of lower group participants who answered the question correctly

$\mathrm{B}_{\mathrm{A}}$

$P_{A}=B_{B} \quad:$ proportion of upper group students who correctly answer the test item

$P_{B}=J_{B} \quad$ : proportion of lower group students who correctly answer the test item

rpret the value of discrimination index, use of distinguishing clarification from

Arikunto (2012), and it is shown in the Table below:

Table 6. Criteria of Discrimination Index of Question

\begin{tabular}{|l|l|}
\hline Discrimination Index(D) & Interpretation \\
\hline $0,00-0,20$ & Poor \\
\hline $0,21-0,40$ & Moderate \\
\hline $0,41-0,70$ & Good \\
\hline $0,71-1,00$ & Excellent \\
\hline
\end{tabular}


The result as follows:

Table 7. Discrimination Index of Question

\begin{tabular}{|c|c|c|}
\hline Number of Question & Discrimination Index & Interpretation \\
\hline $\begin{array}{c}4,6,8,9,11,13,20,23,24,26,30, \\
37,44,46\end{array}$ & $0.00-0.0,11$ & Poor \\
\hline $\begin{array}{c}3,10,12,14,15,16,21,27,42,43,45, \\
48,49\end{array}$ & $0.22-0.33$ & Moderate \\
\hline $\begin{array}{c}2,17,18,19,22,31,32,33,34,35,36, \\
39,40,41,50\end{array}$ & $0.44-0.66$ & Good \\
\hline 28 & $0.88-1.00$ & Excellent \\
\hline
\end{tabular}

According to the table above, there were 14 items in poor category, 13 items in moderate category, 15 items in good category and 1 item in excellent category.

Level of Difficulty

Good question is a question that is used to determine the level of difficulty of that question. The aim is to find out whether the question is considered difficult, moderate or easy. The following formula are used to calculate the index of an item:

$$
P=\frac{B}{J S}
$$

(Arikunto, 2012)

Where;

P: Difficulty Level

B: The number of students who answered the questions with correct answers

JS: Number of students' participants in the test

Calculating the result is to interpret the criteria classification from the level of difficulty according to Arikunto (2012).

Table 8. Criteria of Difficulty Level

\begin{tabular}{|l|l|}
\hline Index of Difficulty $(\mathrm{P})$ & Interpretation \\
\hline $0,00-0,30$ & Difficult \\
\hline $0,31-0,70$ & Moderate \\
\hline $0,71-1,00$ & Easy \\
\hline
\end{tabular}

The result as follows:

Table 8. Difficulty Level

\begin{tabular}{|c|c|c|}
\hline Number & $\begin{array}{c}\text { Index of } \\
\text { Difficulty }\end{array}$ & Difficulty Level \\
\hline $6,7,24,31,37,42,43,45,47$ & $0.03-0.27$ & Difficult \\
\hline $10,16,17,21,22,23,25,28,29,34$ & $0.36-0.69$ & Moderate \\
\hline $\begin{array}{c}1,2,3,4,5,8,9,11,12,13,14,15,18,19,20,26,27, \\
30,32,33,35,36,38,39,40,41,44,46,48,49,50\end{array}$ & $0.72-1.00$ & Easy \\
\hline
\end{tabular}


According to the result above, most of the items are in the level 0.72-1.00, which are 31 items. So, the difficulty level of the test is Easy.

The Recapitulation of The Result of Pilot Test

This research used 39 questions for pre-test as well as post-test. To analyze the result of the data, the Anates program was used. The recapitulation of the test result can be seen in the table below.

Table 9. The Recapitulation of Pilot Test

\begin{tabular}{|c|c|c|c|}
\hline $\begin{array}{l}\text { Number of } \\
\text { questions }\end{array}$ & Validity & Difficulty level & Discrimination \\
\hline 1 & Not valid & Easy & Poor \\
\hline 2 & High & Easy & Good \\
\hline 3 & Moderate & Easy & Moderate \\
\hline 4 & Very low & Easy & Poor \\
\hline 5 & Not valid & Easy & Poor \\
\hline 6 & Very low & Difficult & Poor \\
\hline 7 & Not valid & Difficult & Poor \\
\hline 8 & Not valid & Easy & Poor \\
\hline 9 & Not valid & Easy & Poor \\
\hline 10 & Very low & Moderate & Moderate \\
\hline 11 & Not valid & Easy & Poor \\
\hline 12 & Low & Easy & Moderate \\
\hline 13 & Not Valid & Easy & Poor \\
\hline 14 & Moderate & Easy & Moderate \\
\hline 15 & Very low & Easy & Moderate \\
\hline 16 & Low & Moderate & Moderate \\
\hline 17 & Moderate & Moderate & Good \\
\hline 18 & Moderate & Easy & Good \\
\hline 19 & High & Easy & Good \\
\hline 20 & Moderate & Easy & Poor \\
\hline 21 & Low & Moderate & Moderate \\
\hline 22 & Moderate & Moderate & Good \\
\hline 23 & Very low & Moderate & Poor \\
\hline 24 & Very low & Difficult & Poor \\
\hline 25 & Not valid & Moderate & Poor \\
\hline 26 & Very low & Easy & Poor \\
\hline 27 & Moderate & Easy & Moderate \\
\hline 28 & Moderate & Moderate & Excellent \\
\hline 29 & Not valid & Moderate & \begin{tabular}{|l|} 
Poor \\
\end{tabular} \\
\hline 30 & Low & Easy & Poor \\
\hline 31 & Moderate & Difficult & Good \\
\hline 32 & High & Easy & Good \\
\hline 33 & Moderate & Easy & Good \\
\hline 34 & Moderate & Moderate & Good \\
\hline 35 & Moderate & Easy & Good \\
\hline 36 & Moderate & Easy & Good \\
\hline 37 & Low & Difficult & Poor \\
\hline 38 & Not valid & Easy & Poor \\
\hline
\end{tabular}




\begin{tabular}{|l|l|l|l|}
\hline 39 & Moderate & Easy & Good \\
\hline 40 & Moderate & Easy & Good \\
\hline 41 & Moderate & Easy & Good \\
\hline 42 & Very low & Difficult & Moderate \\
\hline 43 & Very low & Difficult & Moderate \\
\hline 44 & Low & Easy & Poor \\
\hline 45 & Low & Difficult & Moderate \\
\hline 46 & Low & Easy & Poor \\
\hline 47 & Not valid & Difficult & Poor \\
\hline 48 & Moderate & Easy & Moderate \\
\hline 49 & Moderate & Easy & Moderate \\
\hline 50 & High & Easy & Good \\
\hline
\end{tabular}

Based on the recapitulation test, this research used 39 questions for pre-test and post-test. They were question number: $2,3,4,6,10,12,14,15,16,17,18,19,20,21,22,23,24,26,27,28$, $30,31,32,33,34,35,36,37,39,40,41,42,43,44,45,46,48,49$, and 50. Those are based on the result of questions analysis; that the 39 questions was used to measure the students' ability in improving students' reading comprehension.

\section{Data Analysis}

The researcher used the statistical program in analyzing the data such as SPSS, Anates, and Microsoft Excel.

\section{Normalized Gain}

To determine the improvement of students' reading comprehension, the researcher will perform an analysis on the results of the pretest and post-test. Analyzing will be performed using Normalized Gain.

$$
\mathrm{g}=\quad \begin{gathered}
\% \text { posttest }-\% \text { pretest } \\
100 \%-\% \text { pretest }
\end{gathered}
$$

(Hake, 1999)

Where;

g: average normalized gain

$\%$ pretest: percentage of pre-test scores

$\%$ posttest: percentage of post test scores

The criteria of normalized gain according to Hake (1999) can be seen in the table below:

Table 9. The Criteria of Normalized Gain:

\begin{tabular}{|c|c|}
\hline Gain $(\mathrm{g})$ & Category \\
\hline $\mathrm{g} \geq 0.70$ & High \\
\hline $0.30<\mathrm{g} \leq 0.70$ & Moderate \\
\hline $\mathrm{g}<0.30$ & Low \\
\hline & \\
\hline
\end{tabular}

The researcher used the statistical program in analyzing the data such as SPSS, Anates, 
and Microsoft Excel.

Normalized Gain

To determine the improvement of students' reading comprehension, the researcher will perform an analysis on the results of the pretest and post-test. Analyzing will be performed using Normalized Gain.

$$
\mathrm{g}=\frac{\% \text { posttest }-\% \text { pretest }}{100 \%-\% \text { pretest }}
$$

(Hake, 1999)

Where;

$\mathrm{g}$ : average normalized gain

$\%$ pretest: percentage of pre-test scores

$\%$ posttest: percentage of post test scores

The criteria of normalized gain according to Hake (1999) can be seen in the table below:

Table 10. The Criteria of Normalized Gain:

\begin{tabular}{|c|c|}
\hline Gain $(\mathrm{g})$ & Category \\
\hline $\mathrm{g} \geq 0.70$ & High \\
\hline $0.30<\mathrm{g} \leq 0.70$ & Moderate \\
\hline $\mathrm{g}<0.30$ & Low \\
\hline & \\
\hline
\end{tabular}

\section{Normality Test}

Normally test is done to see whether the normalized gain score is normal or not. In this normality test, normalized gain may be considered normally distributed if the significance (Sig) $>\alpha 0.05$ for the normality test. Shapiro-Wilk test is used because; it is the most powerful normality test as said by Razali and Wah (2011).

The formula is:

Explanations:

$$
W=\frac{\left(\sum_{i=1}^{n} a_{i} x_{(i)}\right)^{2}}{\sum_{i=1}^{n}\left(x_{i}-\bar{x}\right)^{2}}
$$

W: gain normality test normalized

$\mathrm{X}_{\mathrm{i}}$ : sample data $\mathrm{i}$

$\mathrm{a}_{\mathrm{i}}$ : constants derived from the average value, variance and covariance of the sample distribution order $\mathrm{n}$ from normal distribution

$\bar{x}$ : average sample data

Based on the statistical test of the rejection criteria, namely $\mathrm{H}_{0}$ rejected if

$$
\mathrm{W}_{\text {count }} \geq \mathrm{W}_{\text {table }}
$$

Then the data obtained was processed with SPSS. Criteria based on SPSS data processing, in this study as follows:

The hypotheses are;

$\mathrm{H}_{0}$ : Normalized gain data is normally distributed

$\mathrm{H}_{\mathrm{a}}$ : Normalized gain data is not normally distributed

$\mathrm{H}_{0}$ is rejected if the sig value is $\leq 0.05$

$\mathrm{H}_{0}$ is not rejected if the sig value is $>0.05$ 


\section{Homogeneity Test}

To determine whether the population variances are homogeneous or not which means having the same basic qualities, the researcher will use the homogeneity test based on the result of normality test.

The hypotheses will be used are:

$H_{0}$ : The population variances are homogenous

$\mathrm{Ha}$ : The population variances are not homogenous

The formula used for this test according to Uyanto (2009):

Where;

$$
\mathrm{F}=\frac{s_{1}^{2}}{s_{2}^{2}}
$$

F: F-value

$\mathrm{S}_{1}^{2}$ : the larger variance

$\mathrm{S}_{2}^{2}$ : the smaller variance

The criteria of Homogeneity test if the data is analyzed with SPSS:

a. The population variances are homogeneous if sig. Value $>\alpha(0.05)$, then $\mathrm{H}_{0}$ is accepted.

b. The population variances are not homogeneous if sig. Value $\leq \alpha(0.05)$, then $\mathrm{H}_{0}$ is rejected.

Hypothesis Testing

From the hypothesis to be tested in this study are:

Ho: $\mu_{1}=\mu_{2}$

Ho: $\mu_{1} \neq \mu_{2}$

Where:

$\mu_{1}$ : Average normalized gain for the group reading comprehension enhancement in group 1

$\mu_{2}:$ Average normalized gain for the group reading comprehension enhancement in group 2

if both of the normalized gain population normally distributed, the test used is ttest.

$$
t=\frac{x_{1}-x_{2}}{s^{D} \sqrt{\left(\frac{1}{n_{1}}+\frac{1}{n_{2}}\right)}}
$$

$$
t=\frac{x_{1}-x_{2}}{S D \sqrt{\left(\frac{1}{n_{1}}+\frac{1}{n_{2}}\right)}} \quad \text { With } \quad S D=\sqrt{\frac{\left(n_{1}-1\right) S_{1}^{2}+\left(n_{2}-1\right) S_{2}^{2}}{n_{1}+n_{2}-2}}
$$

Where;

$$
\begin{aligned}
& \bar{X}_{1}=\text { Mean score for Think-Pair-Share } \\
& \bar{X}_{2}=\text { Mean of Listen-Read-Discuss } \\
& \mathrm{n}_{1}=\text { Think-Pair-Share sample size } \\
& \mathrm{n}_{2}=\text { Listen-Read-Discuss sample size } \\
& \mathrm{S}_{1}=\text { Standard deviation of Think-Pair-Share } \\
& \mathrm{S}_{2}=\text { Standard deviation of Listen-Read-Discuss }
\end{aligned}
$$

Criteria of t-test: 
1. If, $\mathrm{p}$ Value (Sig) $\leq \alpha(.050): \mathrm{H}_{0}$ is rejected. It means there is significant difference in the students' reading comprehension enhancement between those who are taught through TPS and those who were taught through LRD strategy.

2. If, $\mathrm{p}$ Value (Sig) $>\alpha(.050): \mathrm{H}_{0}$ is not rejected. It means there is no significant difference in the students' reading comprehension enhancement between those who are taught through TPS and those who were taught through LRD strategy.

If one or both of the normalized gain population is not normally distributed, then the nonparametric statistic Man Whitney test will be used.

\section{Data Analysis And Findings}

Test of Normality

The researcher used the test of normality to observe probability distribution of the data. The result can be seen on the table below.

Table 11. Normality Test

\begin{tabular}{|l|r|r|r|}
\hline & \multicolumn{3}{|c|}{ Shapiro-Wilk } \\
\cline { 2 - 4 } & Statistic & Df & \multicolumn{1}{c|}{ Sig. } \\
\hline GAIN_TPS & .964 & 28 & .422 \\
GAIN_LRD & .979 & 28 & .836 \\
\hline
\end{tabular}

Based on the table, it can be concluded that the population of the data are normally distributed for both classes with the significant value are, 0.422 and $0.836>\alpha(0.05)$. This research used the output from the Shapiro Wilk because it is the powerful normality test, as written by Razali and Wah (2011). If both data have p.Value (sig) $>\alpha=0.05$ it means data is normally distributed and if the $\mathrm{p}$.Value (sig) $<\alpha=0.05$ it means data is not normally distributed. Test of Homogeneity of Variance

To see the homogeneity of population variances, homogeneity test was done. The result can be seen on the table below:

Table 12. Homogeneity of Variance

\begin{tabular}{|c|c|c|c|}
\hline Levene Statistic & df1 & df2 & Sig. \\
\hline 2.901 & 1 & 57 & .094 \\
\hline
\end{tabular}

According to the data above, the significant value is $0.094>\alpha(0.05)$, therefore it means that the population variances between TPS and LRD were homogenous. The data is homogenous if $\mathrm{p}$-Value (sig) $>\alpha=0.05$ it means data is homogenous and if $\mathrm{p}$-Value $(\mathrm{sig})<\alpha=0.05$ it means data is not homogenous.

Hypothesis Testing

According to the result of the data calculation the data was normally distributed, therefore the researcher used Independent Sample t-test.

Researcher set two presumptions to know the hypothesis is rejected or not:

1. If, $p$ Value (Sig) $\leq \alpha(.050)$ : Ho is rejected. It means there is significant difference of students' reading comprehension enhancement between those who were taught through TPR and those who were taught through LRD strategy. 
2. If, $p$ Value ( $\mathrm{Sig}) \geq \alpha$. (.050): Ho is not rejected. It means there is no significant difference of students' reading comprehension enhancement between those who were taught through TPS and those who were taught through LRD strategy.

The result calculation can be seen on the following table

Table 13. The Independent Sample T-test

\begin{tabular}{|r|r|r|r|r|r|}
\hline $\begin{array}{r}\text { Levene's Test } \\
\text { for Equality of } \\
\text { Variances }\end{array}$ & \multicolumn{3}{|c|}{ t-test for Equality of Means } \\
\hline F & Sig. & T & Df & Sig. (2-tailed) \\
\hline $\begin{array}{r}2.90 \\
1\end{array}$ & .094 & -1.478 & 57 & & .145 \\
\hline
\end{tabular}

The result of the data in table above showed that $\rho$-value $=0.145>\alpha(0.05)$. It means that Ho is not rejected. Therefore, it is concluded that there is no significant difference on the student's reading comprehension enhancement between those who were taught through TPS and those who were taught through LRD strategy. According to the data, the researcher used the data of equal variances assumed concern that the sample data was distributed homogenous and sig (2-tailed).

\section{Discussion of the Research Finding}

From the result of the data, it showed that there is no significant difference on students' reading comprehension enhancement between those who were taught through Listen-Read-Discuss and those who were taught through Think-Pair-Share. It can be said, both methods are applicable and good proven by the data previously discussed.

The data from Think-Pair-Share and Listen-Read-Discuss class showed that the students' reading comprehension increased. It can be seen from the mean of the pre-test score which are 52, $84 \& 45,96$ to the mean of post-test score, 71, $35 \& 71,00$. According to the researcher's experience in the field, the students from both classes found that the strategies used were interesting to learn English by using LRD and TPS strategy and during the lesson students could find their way to learn. The more they learned English through both TPS and LRD strategy, the more they showed their enhancement in class.

The researcher found that the students were more enthusiastic in reading English book. Therefore, almost all the students really aimed to be capable to read English passages in order they can achieve their goals, so even though they found some difficulties while reading they still read it until it is finished. The researcher also helped when the students asked the meaning of some words and helped students how to pronounce some words that students cannot pronounce.

In Indonesia, there has been a study in Juwiring, entitled: "The Effectiveness of Think - Pair - Share Strategy (TPS) to teach Reading Comprehension at the eighth grade of the SMP N.1 Juwiring" done by Rohman (2017). The findings of this study revealed that the implementation of TPS was successful when viewed from some dimensions. The students who were taught using Think-Pair-Share have better reading comprehension.

For Listen-Read-Discuss strategy, students enhanced their reading comprehension. It can be stated that through LRD strategy students enjoyed more and become motivated to learn English. This study was also supported by Purwanti (2017) with the study entitled: "The use of Listen-Read-Discuss Strategy to improve Students' Reading Comprehension of the Eight 
Grade Students At SMPN 2 Tembilahan", which said that the use of LRD strategy found that the students enjoyed more in learning reading and comprehend the text easily.

\section{Conclusion}

After analyzing the data, the researcher came up with a conclusion to answer the statement of the problem in chapter 1, that there is no significant difference between those who were taught through TPS strategy and those who were taught through LRD strategy.

\section{Recommendation}

Based on the research findings, the researcher gave several recommendations as follow:

Teachers: It is recommended that teachers use these two methods as an alternative strategy in teaching English Reading Comprehension, especially for junior high school students because, it is already proven by the researcher and the result showed that the students' reading comprehension significantly increased. But LRD is better in enhancing reading comprehension, it is shown from the mean score, the standard deviation and also according to researcher's experience in the field. Students who were taught using LRD strategy had better comprehension of the material than students who were taught using TPS strategy. Researchers: The researcher hoped that the result of this study can be used as additional references for future researchers in different levels and contexts.

\section{References}

Afrilianti, (2014). The Effectiveness of Using TPS (Think-Pair-Share) Strategy to Improve Students' Reading Comprehension of The First Grade At MTSN Aryojeding Rejotangan Tulungagung 2013/2014. Tulungagung: State Islamic Institude (IAIN).

Ahmadi, M.R., (2017). The Impact of Motivation on Reading Comprehension. International Journal of Research in English Education. 2(1).

Amelia, R.K., (2016). Using Think-Pair-Share Stratey to Improve Vocabulary and Reading Comprehension Achievement of Eight Grade Students, The Journal of English Literacy Education, 3(2).

Annisa, Z., (2013). Improving Students' Reading Comprehension Through Think- PairShare Technique (A Classroom Action Research at the Eight Grade Students of SMP Muhammadiyah Sumbang in Academic Year 2012/2013). Purwokerto: Universitas Muhammadiyah.

Arif, M. (2014). Penerapan aplikasi anates bentuk soal pilihan ganda. Jurnal Ilmiah Edutic, Vol. 1, No. 1, pp. 1-9.

Arikunto, S., (2012). Dasar-dasar Evaluasi Pendidikan. Edisi 2. Jakarta: Bumi

Aksara. 
Carss, W.D., (2007). The Effects of Using Think-Pair-Share During Guided Reading Lesson. New Zealand: The University of Waikato.

Copyright 2012 S2 TEM Centers SC $\underline{\text { ww.s2temsc.org }}$

Dwiono, R., (2017). Listen-Read-Discuss in Teaching and Learning Reading Comprehension: A Case Study of Private Senior High School in Lampung. Proceeding of 2nd International Conference of Arts Language And Culture. p. 437.

Elfa, Y., (2017). The Influence of Using Listen-Read-Discuss (LRD) Strategy Towards Students'reading Comprehension on Narrative Text at The Firts Semester of The Eleventh Grade of SMA Perintis 1 Bandar Lampung in 2017/2018 academic Year. Lampung: Raden Intan State Islamic University.

Ergul, C., (2012). Evaluation of reading Performance of students with readimg problems for Theory \& Practice, 12 (3) 2051-2057.

Falianti, E., \& Rosiana, (2013). The Comparison of Reading Comprehension in Descriptive text Instruction using Case Study and Analytical Team of Students at Senior High School of State 1 Kotagajah Academic Year 2012/2013. Muhammadiyah University of Metro. 2 (2) 2089 -3345.

Fitrahady, R., (2015). The Use of Think-Pair-Share Technique in Teaching Reading Comprehension. Banda Aceh: Universitas Syiah Kuala.

Gewati, M. 29 august, 2016.” Minat Baca Indonesia Ada di Urutan ke-60 Dunia", Kompas.com.

Gibson, K.D., (2009). Teacher's Perpection of Strategy based Reading Instruction for Reading Comprehension. CA: Dominican University of California.

Gurk, N.K.A., (2016). The Effect of Cooperative Learning Techniques on Intermediate Iranian EFL Learners' Reading Comprehension and Reading Strategies. Journal of Studies in Education. 6 (4) 40.

Gusdin, s., (2014). Improving Reading Comprehension Through Think-Pair-Share Technique at The Tenth Grade Students of SMAK Santo Yoseph Denpasar in Academic Year 2013/2014. Denpasar.

Hake, R. R. (1999). Analyzing change/gain scores. [Online]. Available at: http://www.physics.indiana.edu/ sdi/AnalyzingChange-Gain.pdf [June $20^{\text {th }}, 2017$ ]

Hake, R. R. (2007). Design-based research in physics education: A review in A. E. Kelly, R.A. Lesh, \& J. Y. Back, eds. (in press), handbook of design research methods in mattematics, science, and technology education. Erlbaum. [Online]. Available at: www. physics. indiana. edu. / hake/DBR-Physics3. pdf.

Has, R.S., Gultom, E., et al., (2016). The Effect of Think-Pair-Share Strategy on the 
Text at SMAN 1 Tempuling.

Ability of the first year Students in Comprehending Descriptive

Hasanah, N.U., (2016). Improving Students' Reading Comprehension in Narrative Text with the Medium of Story Map. (A Classroom Action Research at the Eighth Grade of SMP Nurul Islam Semarang in the Academic Year of 2015/2016).

Hutomo, A.I., (2017). Improving Students' Reading Comprehension Through

Listen-Read-Discuss (LRD) Strategy, Surakarta: Slamet Riyadi University.

Jennings, J., aldwell J., Lerner J., (2010). Reading Problems Assessment and Teaching

Strategies. $\left(6^{\text {th }}\right.$ ed.) Boston: Deasson.

Juliana, (December 2017), The Comparative Impacts of Using Lexical Glossing and Inferencing Strategies on Students'Reading Comprehension. Andvanced in Language and Literary Studies. 9(1).

Karimi, L., \& Veisi, F. (2016). The impact of teaching critical thinking skills on reading comprehension of Iranian intermediate EFL learners. Theory and Practice in Language Studies, 6(9), 1869-1876.

Katemba, C., V. (2019), Students' Vocabulary Enhancement at Grade 10: A

Comparative Study Using CALL \& MALL in Indonesia. CALL-EJ, 20(1), 87-114. http://callej.org/journal/20-1/Katemba2019.pdf

Katemba, C.V. (2013), Anxiety Level of Indonesian Students and Its Relationship To Academic Achievement In English. Journal of Education and Practice Vol.4 No.27 pp. 1-9. Retrieved from http://www.iiste.org/Journals/index.php/JEP/article/view/9873/10097

Khuawan \& Dennis. (2017). A study of English Reading Comprehension using ContentBased Instruction Approach. International Journal of Research- Granthaalayah.

Kustanti, D. (January 2016). Kesulitan dan Solusi Pembelajaran English Reading Text. Jurnal al-Tsaqafa Volume 13, No. 01.

Lacina, J., Bauml, M., \& Taylor, E. R. (2016). Promoting resilience through readalouds YC Young Children, Institute of Educaton Sciences, 71(2),16-27.

Leipzig, D.H., (2001), “What is Reading?” http://www.readingrockets.org/article/whatreading, Accessed September 092018.

Leon, N, Laying, J., \& Soka. M., (2012). What does it mean to comprehend one reads? Research Foundations of mimio Reading Individualized Instruction. Mimio, a Newell Rubbermaid Company.

Lyman, F. (1981). The Responsive Classroom Discussion: The Inclusion of All Students.Mainstreaming Digest. University of Maryland, College Park, MD. 
Mahfirah, N.I., (2018). Improving Student's Reading Comprehension ThroughThinkPair-Share at The Second Language Class Of MAN II Batu Malang. Journal of Education, Social and Religious. 14 (1).

Manzo, A.V., \& Casale, U.P. (1985). Listen-Read-Discuss: A content reading heuristic. Journal of Reading, 28, 372-734.

Marlina, L., (January 2012). Learning English as Foreign Language in Indonesia through English Children's Literature. International Journal of Literacies 19(4):41-51.

МБ Козак, (2017). The Types of Reading and Exercises for Teaching Reading, RFAML_Journ_Pilot.indd. http://www.eosnova.edu/PDF/osnova100696.pdf.

Accessed September 092018.

Morisson, N., (2014). How School Are Breaking Down The Language Barrier for EAL Students. The Guardian International Edition.

Murni, D.S., (2014). Improving Studets'Reading Comprehension Through Listen-ReadDiscuss (LRD) Strategy (A Classroom Action Research at Class X-

1 of SMA Negeri 1 Musuk Boyolali in 2014/2015 Academic Year), $1(2)$.

Ningsih, A.A., (2013). Implementasi Model LRD (LISTEN-READ-DISCUSS) Untuk Meningkatkan Maharah Qira'ah Mahasiswa PPBA Fakultas Hidaya. Malang: Universitas Islam Negeri Maulana Malik Ibrahim.

Pang, et.al., (2009). "Teaching Reading. International Academy of Education", http://www.ibe.unesco.org/publication/EducationalPracticeSeriesPdf/pra ct 12e.pdf. Accesssed September 092018.

Pariska, D., (2016). The Effect of Using Listen-Read-Discuss (LRD) Strategy and Students' Prior Knowledge on The Second Years Students At MA

Daarun Nahdhah Thawalib Bangkinang.Pekanbaru: State Islamic Sultan Syarif Riau.

Pertiwi, K., (2015). Penerapa Model Pembelajaran Koorperatif Tipe Jigsaw untuk meningkatkan Motivasi dan hasil belajar pada mata pelajaran sosiologi siswa kelas XI IPS 1 SMA N 5 Surakarta tahun pelajaran (2015/2016).

Purnamasari, R. (2017). A comparison between word tree branch and interactive word wall methods to improve students' vocabulary. Bandung. Universitas Advent Indonesia.

Purwanti, S.E., (2017). The Use of LRD (Listen-Read-Discuss) Strategy to Improve Students' ReadingComprehension of The Second Grade Studentsat SMP N.2 Tembilahan, English Journal of Indragiri (EJI).1(2).

Putri, R., (2013), The Effect of Using LRD (Listen-Read-Discuss) Strategy

TowardReading Comprehension of The Second Year Students at

State Junior High School 9 Tapung Kampar Regency, Pekanbaru: University 
of Sultan Syarif Kasim Riau.

Razali, N.M. and Wah, Y. B., (2011). Power Comparison of Shapiro-Wilk,

Kolmogrov-Smirnov, Lilliefors and Anderson Darling Tests. Jornal of Statistical Modeling and Analitics, Vol 2.

Retmawasari, N., (2013), Keefektifan Strategi Listen-Read-Discuss (LRD) Dalam Pembelajaran Membaca Pemahaman Pada Siswa Kelas XI SMA Negeri 1 Tempel Yogyakarta.

Richards, J. C. and Schmidt, R., (2002). Longman Dictionary of Language Teaching \& Applied Linguistics. London: Pearson Educational Limited.

Ridwan, N.A. (2016). Using Think-Pair-Share (TPS) to Improve the Reading Comprehension of Class VIII G Students of SMP Negeril Sleman in The Academic Year of 2016/2017.

Rohman, F. (2017). The Effectiveness of Think - Pair - Share Technique (TPS) to teach Reading Comprehension (An Experimental Study at The Eight Grade Students of SMP N 1 Juwiring in 2013/2014 Academic Year).

Romli, M (2014). Improving the Students' Reading Comprehesion of Narrative Text through Story Mapping.

Rusli, et.al., (2012). Improving Students' Ability in Reading Comprehension of a Narrative Text Through Think-Pair-Share Technique.University Pontianak.

Sapsuha, S., \& Bugis, R., (Novenber 2013). Think Pair Share Technique to Improve Students' Reading Comprehension. ICE-Ed conference. ELT

Practices in Asia: Challenges and Opportunities. Universitas Iqra Buru, Maluku.

Sari, A.R., (2012). Improving Students' Reading Skill by Using Think-Pair-Share (TPS) (A Classroom Action Research at The First Grade of SMP N.8 Surakarta in the Academic Year of 2011/2012).

Siburian, T.A., (2013). Improving Students' Achievement on Writing Descriptive Text Through Think-Pair-Share. International Journal of Language Learning and Applied Linguistics World (IJLLALW). 3 (3). 30-43.

Supranto, J. (2009). Statistik teori dan aplikasi edisi ketujuh. Jakarta: Erlangga.

Uyanto, S. S. (2009). Pedoman analisis data dengan SPSS. Yogyakarta: Graha Ilmu.

Supriyani, P., Sudirman, et al., (2017). The Use of Think Pair Share Technique to Improve Students Reading Comprehension in Report Text (Research report) Bandar Lampung: Universitas Lampung, Vol. 6, (8), 1-2.

Suryanita, N.M.A., Suryadi, M., \& Suditha, I.N. (2013). Penerapan Model Pembelajaran Kooperatif Tipe TPS untuk Meningkatkan Aktivitas dan Hasil Belajar Siswa pada Mata 
Pelajaran Geografi Kelas X A SMA Negeri 1 Bebandem Kecamatan, Kabupaten KarangasemTahun Pelajaran (2012/2013. Pg 3).

Usman, hi. A., (2015). Using the Think-Pair-Share Strategy to Improve Students' Speaking Ability at Stain Ternate. Ternate. State Institute for Islamic Studies (IAIN). 